\title{
Wild pig (Sus scrofa) as prey of the Common Vampire Bat (Desmodus rotundus)
}

\author{
Edwin L. Hernández-Pérez ${ }^{1 *}$, Guillermo Castillo-Vela ${ }^{1}$, Gabriela García-Marmolejo², Mauro Sanvicente López ${ }^{3}$ and Rafael Reyna-Hurtado \\ ${ }^{1}$ Departamento de Conservación de la Biodiversidad, El Colegio de la Frontera Sur, Unidad Campeche. Av. Rancho, Polígono \\ 2A, CP. 24500, Ciudad Industrial Lerma. Campeche, México. Email: e.hperez@hotmail.com (ELHP), gcastillo@ecosur.mx (GCV), \\ rreyna@ecosur.mx (RRH) \\ ${ }^{2}$ Cátedra Conacyt-Ecosur, Departamento de Conservación de la Biodiversidad, El Colegio de la Frontera Sur, Unidad Campeche. \\ Av. Rancho, Polígono 2A, CP. 24500, Ciudad Industrial Lerma. Campeche, México. Email: gabrielagarciamarmolejo@gmail.com \\ (GGM) \\ ${ }^{3}$ Colegio de Postgraduados, Campus Puebla. Carretera federal México-Puebla km. 125.5, (Boulevard Forjadores), CP. 72760, \\ Puebla. Puebla, México. Email: sanvicentemauro@yahoo.com (MSL) \\ ${ }^{*}$ Corresponding author
}

The common vampire bat (Desmodus rotundus), is the hematophagous bat with the broadest distribution and the only one that preys on wild mammals. However, when the abundance of domestic species increases, D. rotundus tends to feed on horses, domestic pigs, and poultry. The presence of Wild pigs in Laguna de Términos, Campeche, represents an increase in prey availability, a factor that fosters the growth of bat populations in the region. Records were obtained with camera traps in the area of influence of the Laguna de Términos Flora and Fauna Protection Area, Campeche. Camera traps were placed on trees at the edge of trails for the recording of Wild pigs (Sus scrofa) and collared peccaries (Pecari tajacu). The photo trapping period ranged from January 25 to August 16, 2018 with a sampling effort of 1,428 trap days. We recorded 18 species of mammals in the five locations studied. Predation of the common vampire bat on Wild pigs was recorded in a single camera trap located in an oil palm plantation (Elaeis guineensis) surrounded by livestock areas and secondary forest fragments. Wild pigs were the only species recorded as being attacked by the common vampire bat. Of all separate records of Wild pigs, $11.7 \%$ ( $n=22$ ) corresponded to photographs and videos of interactions between Wild pigs and bats. Vampire bat attacks were recorded between 20:00 and 5:00 h, with a peak of activity around 23:21 h. The increased availability of Wild pigs, together with changes in land use, seemingly foster the growth and expansion of vampire bat populations and, therefore, contribute to a higher incidence of attacks on domestic species. In addition to the negative ecological effects, the presence of Wild pigs involves increasingly important epidemiological implications. Studies on the interaction between common vampire bats and Wild pigs are necessary to assess the risk of disease transmission in the region.

El murciélago vampiro (Desmodus rotundus), es la especie de murciélago hematófago que tiene la mayor área de distribución y la única que se alimenta típicamente de mamíferos silvestres. Sin embargo, si la oferta de especies domésticas aumenta, $D$. rotundus tiende a seleccionar caballos, cerdos y aves de corral. La introducción de especies exóticas que ha resultado en la presencia de los cerdos asilvestrados en el área de Laguna de Términos, Campeche, podría estar detonando un aumento en la disponibilidad de presas y un incremento de las poblaciones del murciélago vampiro en la región. Los principales efectos negativos de la presencia de murciélagos vampiro están ligados al incremento en el riesgo en la transmisión de enfermedades como la rabia. Los registros fueron obtenidos con cámaras trampa en la zona de influencia del Área de Protección de Flora y Fauna Laguna de Términos. Las cámaras trampa fueron colocadas en árboles a un costado de brechas para el registro de cerdos asilvestrados (Sus scrofa) y pecaríes de collar (Pecari tajacu). El periodo de fototrampeo fue del 25 de enero al 16 de agosto de 2018 con un esfuerzo de muestreo de 1428 días trampa. Se registraron 18 especies de mamíferos en las cinco localidades estudiadas. Los eventos de depredación del murciélago vampiro sobre los cerdos asilvestrados ocurrieron en una sola cámara trampa, ubicada en una plantación de palma de aceite (Elaeis guineensis) rodeada por áreas de ganadería y fragmentos de selva secundaria. Los cerdos asilvestrados fueron los únicos registrados como atacados por el murciélago vampiro. El $11.7 \%(n=22)$ del total de los registros independientes de cerdos asilvestrados, corresponden a series de fotografías y videos de la interacción cerdos asilvestrados-murciélago. Los ataques de los vampiro se registraron entre las 20:00 y las 05:00 h, con un pico de mayor actividad alrededor de las 23:21 h. El incremento en la disponibilidad de cerdos asilvestrados, en conjunto con cambios en el uso de suelo, podrían detonar el aumento y expansión de las poblaciones de vampiros y, por ende, una mayor incidencia de ataques a especies domésticas. Es necesario estudiar la interacción cerdos asilvestrados-vampiros para conocer los efectos en problemas emergentes como la transmisión de enfermedades en la region.

Key words: Campeche; ecological interaction; exotic species; south of Mexico; zoonotic diseases.

(C) 2019 Asociación Mexicana de Mastozoología,www.mastozoologiamexicana.org

\section{Introduction}

Hematophagous bats are endemic to Latin America and are represented by three species: Desmodus rotundus, Diaemus youngi, and Diphylla ecaudata. The common vampire bat (D. rotundus, hereinafter referred to as vampire bat) is the most widely distributed blood-sucking species in America (Barquez et al. 2018) and the only one that preys on wild mammals (Sánchez-Cordero et al. 2011; López-Tello and
Mandujano Rodríguez 2016; Pignaton Gnocchi and SrbekAraujo 2017). However, when the availability of domestic species increases, the vampire bat tends to feed on them more frequently, with an apparent preference for horses, boars, and poultry (Mialhe 2014; Bobrowiec et al. 2015).

Changes in the availability and abundance of wild species, coupled with the intensification and expansion of livestock rising, have contributed to the modification of the 
feeding habits of the vampire bat, resulting in the growth and geographic expansion of its populations (Streicker and Allgeier 2016). The area around Laguna de Términos, Campeche, is a highly fragmented region whose natural areas have been transformed into agricultural and livestock-raising land (Soto-Galera et al. 2010). This region is home to one of the highest livestock densities in the state (INEGI 2007; Robinson et al. 2014), an ideal feature for the establishment of vampire bat populations. The establishment of these populations may trigger economic and public-health issues, because vampire bats are vectors of zoonotic infectious diseases with the potential to infect wild and domestic animals, and even humans (Mayen 2003; da Rosa et al. 2006; Young et al. 2017). Such effects can be exacerbated by the availability of abundant food resources, as those derived from the introduction of invasive exotic species such as the European Wild pig (Sus scrofa) and its hybrid variety, the wild pig (Galetti et al. 2016).

The presence of wild pigs in the area adjacent to Laguna de Términos was reported since 2014 (Hidalgo-Mihart et al. 2014). However, it is estimated that the species was introduced for hunting purposes since the early 1990s. Its distribution and abundance have increase since then (Hernández-Pérez et al. 2018), in parallel with the density of cattle and horses as reported by local farmers. The increasing abundance of both livestock and wild pigs in the region means higher prey availability for the vampire bat, probably fostering the growth of their local populations (Delpietro et al. 1992).

The vampire bat is considered as an obligate hematophagous species, as it feeds exclusively on blood (Mayen 2003). There are few studies that accurately describe the type of prey attacked by this bat and its tendency to feed on domestic species (Mialhe 2014; Bobrowiec et al. 2015; Streicker and Allgeier 2016). A useful tool to determine the type of prey attacked by the vampire bat, in addition to molecular studies, has been the recording of observations both directly and through camera traps (Galetti et al. 2016; López-Tello and Mandujano Rodríguez 2016; Pereira et al. 2016; Pignaton Gnocchi and Srbek-Araujo 2017). This work reports the first evidence for Mexico regarding vampire bats attacking wild pigs in Laguna de Términos, Campeche, one of the most important wetlands in Mexico.

\section{Methods}

Photographs were captured with camera traps in the area of influence of the Laguna de Términos Flora and Fauna Protection Area (APFFLT), Campeche, in southern Mexico (Figure 1). Camera traps were installed at $50 \mathrm{~cm}$ from the ground on trees adjacent to trails where we found traces of wild pigs and collared peccaries, as part of the project "Distribución y relaciones ecológicas entre cerdos ferales (Sus scrofa) y poblaciones nativas de pecaríes" (Hernández-Pérez 2019). A total of 11 camera traps were placed (Cuddeback $^{\otimes}$ Black Flash E3) in five localities, with a distance of at least $500 \mathrm{~m}$ between traps. Camera traps were set to operate 24 hours a day and to capture a series of five photographs and one 20-second video per detection event. The overall photo trapping period considering the five sites took place from 25 January to 16 August 2018, involving a sampling effort of 1,428 trap days. Vampire bats were identified based on the characteristics that allow the species to adopt a quadruped position to land and move on its prey, including the long thumb with pads on its surface, movement lifting the body, and small jumps on the back of its prey (Pereira et al. 2016), and even the modified nasal sheet, typical of the species. A photograph or video of an individual in a camera trap was considered as an independent record when it was separated from the next record in the same camera trap by at least 60 minutes; if more than one individual is viewed in the same photograph or video, then each of these individuals was considered as an independent record. The activity pattern of vampire bats and other species that had at least ten independent records caught in the same camera as the interaction between wild pigs and bats, was evaluated by circular descriptive statistics with the software Oriana 4.0 (Kovach Computing Service 2011).

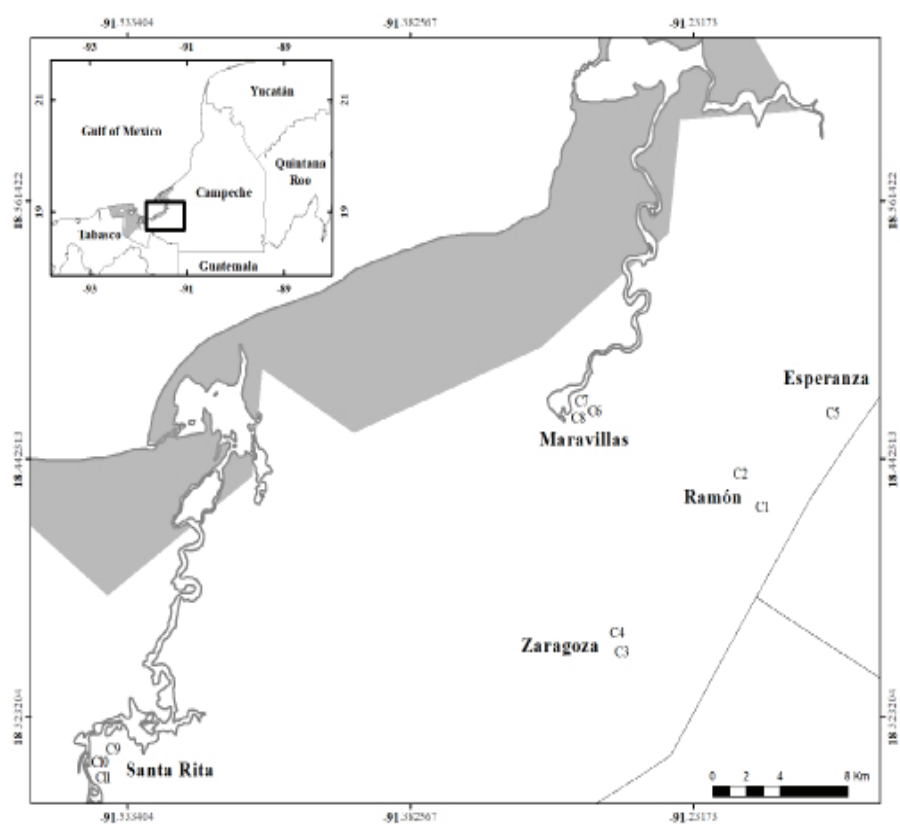

Figure 1. Location of the Laguna de Términos region in southern Mexico. Black dots mark the location of camera traps; the black triangle marks the site where the interaction between wild pigs and vampire bats was recorded.

\section{Results}

A total of 18 species of mammals were recorded in the 11 camera traps installed in the five locations (Table 1). Wild pigs were recorded separately on 213 occasions in six camera traps placed at three different locations.

Predation of the vampire bat on wild pigs was recorded in a single camera trap $\left(18.360464^{\circ} \mathrm{N},-91.269592^{\circ} \mathrm{W}\right)$ installed in an oilpalm (Elaeis guineensis) plantation surrounded by livestock pastures and patches of secondary tropical forest around the village of Ignacio Zaragoza, municipality of Carmen, Campeche (Figure 1). The photo trampling periods for this camera trap ranged from $27 \mathrm{Feb}-$ ruary to 16 April, and from 27 April to 16 August 2018, with a sampling effort of 162 trap days. 


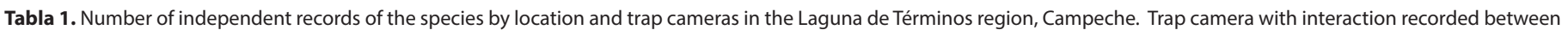
feral pigs and vampire bats is marked with an asterisk.

\begin{tabular}{|c|c|c|c|c|c|c|c|c|c|c|c|c|}
\hline \multirow{2}{*}{ Especie } & \multicolumn{2}{|c|}{ Ramón } & \multicolumn{2}{|c|}{ Zaragoza } & \multirow{2}{*}{$\begin{array}{c}\text { Esperanza } \\
\text { Cam5 }\end{array}$} & \multicolumn{3}{|c|}{ Maravillas } & \multicolumn{3}{|c|}{ Santa Rita } & \multirow{2}{*}{ Total } \\
\hline & Cam1 & Cam2 & Cam3 & Cam4* & & Cam6 & Cam7 & Cam8 & Cam9 & Cam10 & Cam11 & \\
\hline Bos sp. Linnaeus, 1758 & 53 & & 16 & 134 & 82 & & & & & & & 285 \\
\hline Canis latrans Say, 1823 & & & 3 & 42 & & & & & & & 1 & 46 \\
\hline Cuniculus paca (Linnaeus, 1776) & & & & & & 3 & 1 & & & & & 4 \\
\hline Dasyprocta punctata Gray, 1842 & 3 & & & & & & & & & & & 3 \\
\hline Dasypus novemcinctus Linnaeus, 1758 & 2 & & 5 & & & 10 & 5 & & 2 & & & 24 \\
\hline Didelphis marsupialis Linnaeus, 1758 & 5 & 1 & 2 & & & & & & & & & 8 \\
\hline Didelphis virginiana Kerr, 1792 & & 1 & 1 & 11 & & & & & & & & 13 \\
\hline Equus ferus caballus Linnaeus, 1758 & 6 & 3 & & 23 & 2 & & & & & & & 34 \\
\hline Leopardus pardalis Linnaeus, 1758 & 3 & 2 & 2 & & & & & & 1 & 3 & 1 & 12 \\
\hline Nasua narica (Linnaeus, 1776) & 4 & 13 & 18 & & 10 & 1 & & & 10 & 1 & 6 & 73 \\
\hline Odocoileus virginianus (Zimmermann, 1780) & 9 & 8 & 4 & & & 2 & & & & 1 & 4 & 28 \\
\hline Panthera onca (Linnaeus, 1758) & 3 & 4 & & & & & & & & & & 7 \\
\hline Pecari tajacu (Linnaeus, 1758) & 9 & 19 & 2 & & 3 & 3 & 2 & 1 & 2 & 3 & & 44 \\
\hline Procyon lotor (Linnaeus, 1758) & 2 & & 2 & 87 & 3 & 1 & 1 & & 5 & 1 & 1 & 103 \\
\hline Sus scrofa Linnaeus, 1758 & & & 5 & 188 & 8 & & & & 9 & 2 & 1 & 213 \\
\hline Sylvilagus floridanus (J. A. Allen, 1890) & & & & 1 & & & & & & & & 1 \\
\hline Tamandua mexicana (Saussure, 1860) & & & 1 & & & 1 & & & & 1 & & 3 \\
\hline Urocyon cinereoargenteus (Schreber, 1775) & 2 & & 5 & & & & & & & & & 7 \\
\hline
\end{tabular}

This same camera trap captured 486 independent records of seven species: Sus scrofa $(n=188)$, Bos sp. $(n=$ $134)$, Procyon lotor ( $n=87)$, Canis latrans $(n=42)$, Equus ferus $(n=23)$, Didelphis virginiana $(n=11)$, and Sylvilagus floridanus $(n=1)$. Wild pigs were the only species recorded as prey of the vampire bat. Of all the independent records of wild pigs, $11.7 \%(n=22)$ are a series of photographs and videos of the interaction between wild pigs and vampire bats (Figure 2). Most of the records show foraging wild pigs, primarily adult males $(n=7)$, carrying a vampire bat either on one side of the back or on the neck, just behind the ears. Two video records captured a bat flying and landing directly on the lumbar portion (posterior dorsum) of the prey, then moving toward the front. A separate event recorded two vampire bats flying over two juvenil wild pigs. However, there were no records of predation to juvenil pigs.

The species Bos sp., Canis latrans, and Equus ferus showed a cathemeral activity pattern, while Sus scrofa, Procyon lotor, and Didelphis virginiana were more active at night (Figure 3). Attacks of vampire bats on wild pigs took place at night, between 20:00 and 5:00 h, with a peak of activity around 23:21 h (Figure 3).

\section{Discussion}

The predator-prey interaction between vampire bats and wild pigs had only been reported in Brazil (Galetti et al. 2016; Pereira et al. 2016). This work is the first to report evidence of this interaction in Mexico. In spite of the presence of wild species in the study area, including the collared peccary (Pecari tajacu) and the white-tailed deer (Odocoileus virginianus), as well as domestic species such as bovines (Bos sp.) and horses (E. ferus), no attacks on these species were recorded, all of which are also preyed by the vampire bat (Mialhe 2014; Bobrowiec et al. 2015). In interviews to local farmers, no attacks of bats on cows or horses were documented during the period monitored.
Bobrowiec et al. (2015) suggest that the vampire bat tends to feed on domestic pigs when these are easily available. This trend may be related to the activity pattern of pigs, the thickness of the skin, and the presence of a marginal vein in the ears from which the vampire bat can suck sufficient blood for several days. This work documents that wild pigs are attacked by vampire bats most frequently in the Laguna de Términos area. Our findings suggest that vam-

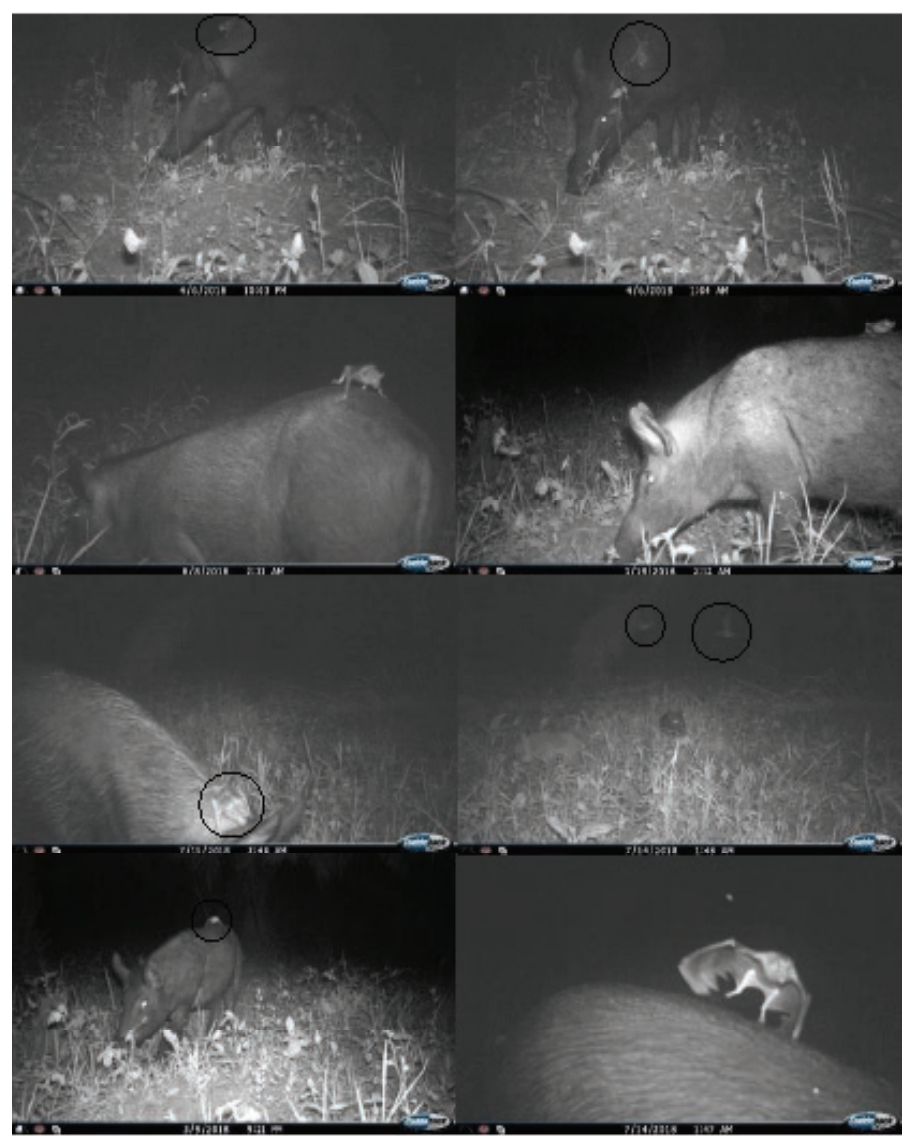

Figure 2. Photographic record of vampire bats (Desmodus rotundus) attacking wild pigs (Sus scrofa) in the Laguna de Términos area, Campeche, Mexico. 

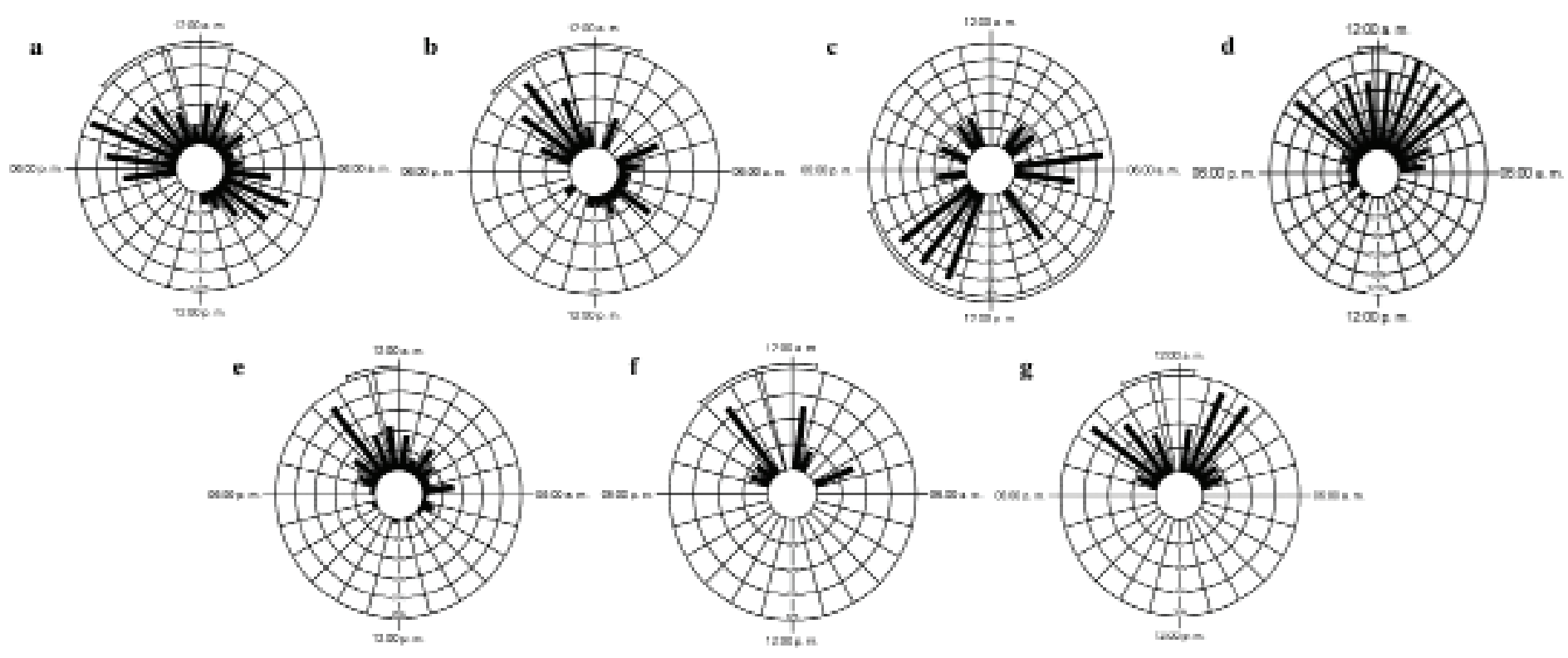

Figure 3. Pattern of activity of a) Bos sp. b) Canis latrans, c) Equus ferus, d) Sus scrofa, e) Procyon lotor, and f) Didelphis virginiana, compared to g) the period when vampire bats (Desmodus rotundus) attacked wild pigs (Sus scrofa) in the Laguna de Términos area, Campeche, Mexico. Bars show the percentage of independent records. The vector represents the $95 \%$ confidence interval.

pire bats are currently feeding preferentially on wild pigs due to the expansion of this exotic prey in the study area in recent years. An alternative explanation is that, unlike the other species recorded, wild pigs are active mainly at night, matching the activity pattern of vampire bats (Figure 3 ). This case implies that the vampire bat would be behaving opportunistically as a non-selective predator, feeding on the most abundant prey species during its period of activity.

The potential distribution for wild pigs as estimated in the study area suggests the expansion of their populations to new sites as a result of the great ecological plasticity of this species, but also of other socioeconomic factors that are promoting the conversion of natural vegetation to oilpalm crops and induced pastures (Hernández-Pérez 2019). The increased availability of wild pigs reported by farmers, together with changes of land use and extensive livestock ranching, constitute a potential scenario for the establishment, growth and expansion of local populations of vampire bats (Pedrosa et al. 2015). This increase may transform the region into a high-risk area for the transmission of zoonotic diseases such as rabies (Gavier-Widén et al. 2012; Young et al. 2017). The rabies virus has been identified in vampire bat populations thriving in the municipalities around Laguna de Términos. The municipality of Candelaria is worth mentioning, as it is currently considered an endemic zone of the disease (SENASICA 2016; SENASICA 2017). However, epidemiological data are limited to reports of positive cases. Under the current context described above, in-depth ecological and epidemiological studies addressing the interaction between wild pigs and vampire bats are needed to assess the risk of transmission of diseases to other wild species and to humans in the region. Wild pigs move freely across the region between areas covered by natural vegetation and anthropized landscapes (Hernández-Pérez 2019), with numbers that will certainly increase in the future based on their high reproductive rate, as a single female can give birth to between eight and 14 pups per year (Taylor et al. 1998). Immediate control measures are required at least in the Laguna de Términos Flora and Fauna Protection Area to manage the expansion and establishment of wild pigs as well as their negative effects on the regional livestock activities, human health, and the conservation of wild populations.

\section{Acknowledgments}

We are grateful to Colegio de la Frontera Sur for funding the project "Distribución y relaciones ecológicas entre cerdos ferales (Sus scrofa) y poblaciones nativas de pecaríes" from which these records were obtained. To Consejo Nacional de Ciencia y Tecnología (CONACyT) for the scholarship 624343 granted to the first author for the completion of postgraduate studies. To the Direction of the Área de Protección de Flora y Fauna Laguna de Términos, Campeche, in particular to J. Nava, for granting the permits to access the reserve. To Idea Wild for its support by donating equipment for the project. To T. Chi for the valuable comments and suggestions to the manuscript. To the community of Ignacio Zaragoza, Carmen, Campeche, in particular, our deepest gratitude to E. Perez Mendez and his family for their support and hospitality during our stay in the field. María Elena Sánchez-Salazar translated the manuscript into English. 


\section{Cited literature}

Barquez, R., S. Pérez, B. Miller, and M. Díaz. 2018. Desmodusrotundus. En: IUCN 2018. The IUCN Red List of Threatened Species. Versión 2018. http://www.iucnredlist.org/. Consultado el 09 de agosto del 2018.

Bobrowiec, P. E. D., M. R. Lemes, And R. Gribel. 2015. Prey preference of the common vampire bat (Desmodus rotundus, Chiroptera) using molecular analysis. Journal of Mammalogy 96:54-63.

da Rosa, E. S. T., I, Kotait, T. F. S. Barbosa, M. L. Carrieri, P. E. Brandao, A. S. Pinheiro, A. L. Begot, M. Y. Wada, R. C. de Oliveira, E. C. Grisard, M. Ferreira, R. J. da Silva Lima, L. Montebello, D. B. A. Madeiros, R. C. M. Sousa, G. Bensabath, E. H. Carmo, and P. F. C. Vasconcelos. 2006. Bat-transmitted Human Rabies Outbreaks, Brazilian Amazon. Emerging Infectious Diseases 12:1197-1202.

Delpietro, H. A., N. Marchevsky, and E. Simonetti. 1992. Relative population densities and predation of the common vampire bat (Desmodus rotundus) in natural and cattle-raising areas in north-east Argentina. Preventive Veterinary Medicine 14:13-20.

Galetti, M., F. Pedrosa, A. Keuroghlian, and I. Sazima. 2016. Liquid lunch- vampire bats feed on invasive feral pigs and other ungulates. Frontiers in Ecology and Environment 14:505-506.

Gavier-Widén, D., J. P. Duff, and A. Meredith. 2012. Infectious Diseases of Wild Mammals and Birds in Europe. Blackwell publisher. Chichester, West Sussex, U.K.

Hansen, M. C., P. V. Potapov, R. Moore, M. Hancher, S. A. Turubanova, A. Tyukavina, D. Thau, S. V. Stehman, S. L. Goetz, T. R. Loveland, A. Kommareddy, A. Egorov, L. Chini, C. O. Justice, and J. R. G. Townshend. 2013. High-Resolution Global Maps of 21st-Century Forest Cover Change. Science 342:850-854.

HeRnÁndeZ-PÉREZ, E. L. 2019. Distribución y relaciones ecológicas entre cerdos ferales (Sus scrofa) y poblaciones nativas de pecaríes. Tesis de maestría. Departamento de Conservación de la Biodiversidad. El Colegio de la Frontera Sur. San Francisco de Campeche, México.

Hernández-Pérez, E. L., G. Castillo-Vela, G. García-Marmolejo, M. Hidalgo-Mihart, M. Sanvicente López, and R. Reyna-Hurtado. 2018. Selección de hábitat y patron de actividad de cerdos ferales y pecaríes en el sur de México. XIV Congreso Nacional de Mastozoología. Mérida, México.

Hidalgo-Mihart, M. G., D. Pérez-Hernández, L. A. Pérez-Solano, F. M. Contreras-Moreno, J. Angulo-Morales, and J. HernándezNava. 2014. Primer registro de una población de cerdos asilvestrados en el área de la Laguna de Términos, Campeche, México. Revista Mexicana de Biodiversidad 85:990-994.

Instituto Nacional de Estadística y Geografía (INEGI). 2007. Anuario estadístico del estado de Campeche Tomo II. Instituto Nacional de Estadística y Geografia. Campeche 2017.

Kovach Computing Service. 2011. Oriana. Anglesey, Wales: https:// www.kovcomp.co.uk/oriana/

López-Tello, E., and S. Mandujano Rodríguez. 2016. Primer registro fotográfico de murciélagos hematófagos Desmodus rotundus (Chiroptera:Phyllostomidae ) alimentandose de Odocoileus virginianus en la Reserva de la Biosfera Tehuacán-Cuicatlán, México. Mammalogy Notes 3:17-19.

Mayen, F. 2003. Haematophagous Bats in Brazil, Their Role in Rabies Transmission, Impact on Public Health, Livestock Industry and Alternatives to an Indiscriminate Reduction of Bat Population. Journal of Veterinary Medicine Series B: Infectious Diseases and Veterinary Public Health 50:469-472.

MialHe, P. 2014. Preferential prey selection by Desmodus rotundus (E. Geoffroy, 1810, Chiroptera, Phyllostomidae) feeding on domestic herbivores in the municipality of São Pedro-SP. Brazilian Journal of Biolpgy 74:579-584.

Pedrosa, F., R. Salerno, F. V. Borges Padilha, and M. Galetti. 2015. Current distribution of invasive feral pigs in Brazil: economic impacts and ecological uncertatinty. Natureza 6:1-8.

Pereira, A., C. Blefari Batista, D. Bender, N. R. dos Reis, and S. BAzILIO. 2016. Report on Desmodus rotundus (Chiroptera, Phyllostomidae) feeding on Sus scrofa (Artiodactyla, Suidae) blood. Sociedade Brasileira de Mastozoologia 77:151-153.

Pignaton Gnocchi, A., and A. C. Srbek-Araujo. 2017. Common Vampire Bat (Desmodus rotundus) feeding on Lowland Tapir (Tapirus terrestris) in an Atlantic Forest remnant in southeastern Brazil. Biota neotropical 17:1-5.

Robinson, T. P., G. R. William Wint, G. Conchedda, T. P. Van Boeckel, V. Ercoli, E. Palamara, G. Cinardi, L. D’Aietti, S. I. Hay, and M. Gilbert. 2014. Mapping the global distribution of Livestock. Plos One 9: e96084. doi:10.1371/journal.pone.0096084

Sánchez-Cordero, V., F. Botello, G. Magaña-Cota, and J. Iglesias. 2011. Vampire bats, Desmodus rotundus, feeding on whitetailed deer, Odocoileus virginianus. Mammalia 75:91-92.

Servicio Nacional de Sanidad, Inocuidad y Calidad Agroalimentaria (SENASICA). 2016. Situación actual de la rabia en bovinos y especies ganaderas. https://www.gob.mx/senasica/ documentos/situacion-actual-de-la-rabia-en-bovinos-yespecies-ganaderas. Consultado el 08 de septiembre de 2018.

Servicio Nacional de Sanidad, Inocuidad y Calidad Agroalimentaria (SENASICA). 2017. Informes de la Situación Zoosanitaria Nacional. http://www.gob.mx/senasica/documentos/informesde-la-situacion-zoosanitaria-nacional-de-2017?state=published. Consultado el 08 de septiembre de 2018.

Soto-Galera, E., J. Piera, and P. López. 2010. Spatial and temporal land cover changes in Terminos Lagoon Reserve, Mexico. Revista de Biologia Tropical 58:565-575.

Streicker, D. G., and J. E. Allgeier. 2016. Foraging choices of vampire bats in diverse landscapes: potential implications for land-use change and disease transmission. Journal of Applied Ecology 53:1280-1288.

Taylor, R. B., E. C. Hellgren, T. M. Gabor, and L. M. Ilse. 1998. Reproduction of Feral Pigs in Southern Texas. Journal of Mammalogy 79:1325-1331.

Young, H. S., I. M. Parker, G. S. Gilbert, A. S. Guerra, and C. L. Nunn. 2017. Introduced Species, Disease Ecology, and BiodiversityDisease Relationships. Trends in Ecology Evolution 32:41-54.

Associated editor: Rafael Avila Submitted: September 26, 2018; Reviewed: January 27, 2019; Accepted:March 27, 2019; Published on line:April 21, 2019. 
